\title{
ANALISIS PENERAPAN PERMENDAGRI NO.113 TAHUN 2014 DALAM PERENCANAAN, PELAKSANAAN DAN PERTANGGUNGJAWABAN APBDes (STUDI KASUS DESA MOTANDOI DAN MOTANDOI SELATAN KECAMATAN PINOLOSIAN TIMUR KABUPATEN BOLAANG MONGONDOW SELATAN)
}

\author{
Delyane Kadjudju $^{1}$, Jenny Morasa ${ }^{2}$, Robert Lambey $^{3}$ \\ 1,2,3 Fakultas Ekonomi dan Bisnis, Jurusan Akuntansi, Universitas Sam Ratulangi, Jl. Kampus Bahu, Manado, \\ 95115, Indonesia \\ E-mail : delyanekadjudju12@gmail.com
}

\begin{abstract}
Village is a unity of the general public that has territorial boundaries authorized to regulate and administer government affairs, the interestsof local communities based on community initiatives, right of origins/ or traditional rights recognized in the governance system of the The Unitary State of the Republic of Indonesia. Financial management of village is all activities that includes planning, implementation, administration, reporting, and financial accountability village. APBDes is the annual financial plan of village government. This research aimed to know planning, implementation, and accounibility village financial management in Motandoi and South Motandoi village, subdistrict East Pinolosian, South Bolaang Mongondow. The method used is descriptive qualitative. The result of the research Motandoi village in planning and implementation phase already approriate with Permendagri number 113 of 2014, but in accountability phase not yet approriate with Permendagri number 113 of 2014, while South Motandoi Village on planning, implementation, and accountability phase already approriate with Permendagri number 113 of 2014.
\end{abstract}

Keywords: Village, Planning, Implementation, Accountability, financial management of Village.

\section{PENDAHULUAN}

\section{Latar Belakang}

Desa adalah desa dan desa adat atau disebut dengan nama lain, selanjutnya disebut Desa adalah kesatuan masyarakat umum yang memiliki batas wilayah yang berwenang untuk mengatur dan mengurus urusan pemerintah, kepentingan masyarakat setempat berdasarkan prakarsa masyarakat, hak asal usul dan/atau hak tradisional yang diakui dan dihormati dalam sistem pemerintahan Negara Kesatuan Republik Indonesia

Desa Motandoi merupakan salah satu Desa yang berada di Kecamatan Pinolosian Timur Kabupaten Bolaang Mongondow Selatan Provinsi Sulawesi Utara. Letak geografisnya berada di pesisir pantai serta daratan yang di kelilingi oleh gunung dan pebukitan. Dengan luas wilayah $615 \mathrm{~km}$ persegi dan jumlah penduduk 1587 yang tersebar di 4 dusun. Selain Desa Motandoi adapun juga Desa Motandoi Selatan. Desa Motandoi Selatan merupakan Desa yang

berada di Kecamatan Pinolosian Timur Kabupaten Bolaang Mongondow Selatan Provinsi Sulawesi Utara. Desa ini dimekarkan berbarengan dengan wacana pemekaran kabupaten/kota, termasuk di kabupaten Bolaang Mongondow yang saat ini sudah menjadi 5 (lima) kabupaten dan salah satunya adalah Kabupaten Bolaang Mongondow Selatan. Desa Motandoi Selatan dimekarkan pada tahun 2012 dan diresmikan menjadi desa persiapan pada tanggal 24 Oktober tahun 2012.

Untuk memperoleh anggaran pendapatan dan belanja desa (APBDes), maka Desa Motandoi dan Desa Motandoi Selatan harus tanggap dalam perencanaan, pelaksanaan, dan 
pertanggungjawaban APBDes untuk memperoleh dana yang nanti akan mereka dapatkan dari kabupaten/kota. Setiap desa tentunya menginginkan kesejahteraan bagi masyarakatnya, dengan adanya dana transfer dari kabupaten/kota ke desa seperti dana desa (DD), Alokasi Dana Desa (ADD), dan bagi hasil pajak dan retribusi. Desa Motandoi dan Desa Motandoi Selatan berharap bisa membantu desa menjadi yang lebih baik dari tahun sebelumnya. Oleh karena itu, Desa Motandoi dan Desa Motandoi Selatan perlu menganalisa proses dari perencanaan, pelaksanaan, dan pertanggunjawaban APBDes agar sesuai dengan permendagri nomor 113 tahun 2014 tentang pengelolaan keuangan desa.

Berdasarkan uraian diatas, maka penulis tertarik dan ingin mengkaji lebih jauh lagi dengan mengadakan penelitian mengenai analisis perencanaan, pelaksanaan, dan pertanggungujawaban APBDes dengan judul "Analisis Penerapan Permendagri No.113 Tahun 2014 Dalam Perencanaan, Pelaksanaan, Dan Pertanggungjawaban APBDes ( Studi Kasus Desa Motamdoi dan Desa Motandoi Selatan Kecamatan Pinolosian Timur Kabupaten Bolaang Mongondow Selatan)".

\section{TINJAUAN PUSTAKA}

\section{Akuntansi}

Akuntansi adalah seni pencatatan, penggolongan, dan peringkasan transaksi dan kejadian yang bersifat keuangan dengan cara berdaya duna dan dalam bentuk satuan uang, dan penginterpretasian hasil proses tersebut. Pengertian seni dalam definisi tersebut dimaksudkan untuk mrnunjukkan bahwa akuntansi bukan merupakan ilmu pengetahuan eksakta atau sains (science) karena dalam proses penalaran dan perancangan akuntansi banyak terlibat unsur pertimbangan (judgment). (Suwardjono, 2014: 5).

\section{Akuntansi Pemerintahan}

Menurut Peraturan Pemerintah Republik Indonesia Nomor 71 Tahun 2010 tentang Standar Akuntansi Pemerintahan, akuntansi adalah proses identifikasi, pencatatan, pengukuran, pengklasifikasian, pengikhtisaran transaksi dan kejadian keuangan, penyajian laporan, serta penginterpretasian atas hasilnya. Akuntansi keuangan daerah adalah proses pengidentifikasian, pengukuran, pencatatan, dan pelaporan transaksi ekonomi (keuangan) dari entitas pemerintah (kabupaten,kota, atau provinsi) yang dijadikan sebagai informasi dalam rangka pengambilan keputusan ekonomi oleh pihak-pihak eksternal entitas pemerintah daerah yang memerlukan. (Widodo, 2016).

\section{Desa}

Desa merupakan salah satu basis dan sumber kegiatan dalam penyelenggaraan pemerintahan dan pembangunan. Desa diharapkan tidak hanya mampu menggerakkan masyarakat untuk berpartisipasi dalam pembangunan, tetapi juga mampu menyelenggarakan pelayanan administrasi desa dengan baik serta dapat mengelola keuangan desa baik dan tertib (Prayudi,2016).

\section{Pemerintahan Desa}

Desa memiliki pemerintahan sendiri. Pemerintahan desa merupakan bagian dari Pemerintahan Nasional yang penyelenggaraannya ditujukan pada pedesaan. Menurut Peraturan Pemerintah Nomor 72 Tahun 2005 pemerintahan desa adalah penyelenggaraan urusan pemerintahan oleh pemerintah desa dan badan permusyawaratan desa (BPD) dalam mengatur dan mengurus kepentingan masyarakat setempat berdasarkan usul-usul dan adat istiadat setempat yang diakui dan dihormati dalam sistem Pemerintahan Negara Kesatuan Republik Indonesia (Iqsan,2016). 


\section{Keuangan Desa}

Menurut Permendagri Nomor 113 Tahun 2014 tentang Pengelolaan Keuangan Desa dinyatakan bahwa keuangan desa adalah semua hak dan kewajiban desa yang dapat dinilai dengan uang serta segala sesuatu berupa uang dan barang yang berhubungan dengan pelaksanaan hak dan kewajiban desa (Suhairi,2016). Undang-Undang No.6 Tahun 2014 tentang Desa yaitu Pasal 71 ayat (1) menyebutkan Keuangan Desa adalah semua hak dan kewajiban Desa yang dapat dinilai dengan uang serta segala sesuatu berupa uang dan barang yang berhubungan dengan pelaksanaan hak dan kewajiban desa.

\section{Anggaran Pendapatan Belanja Desa (APBDes)}

Anggaran Pendapatan Belanja Desa (APBDes) adalah rencana keuangan tahunan pemerintah desa yang dibahas dan disetujui bersama oleh pemerintah desa dan badan permusyawaratan desa, dan ditetapkan dengan peraturan desa. Dengan adanya APBDes penyelenggaraan pemerintahan desa dapat memiliki sebuah rencana pengelolaan keuangan desa yang terstruktur berdasarkan anggaran yang tersedia dan dana yang dipergunakan (Faridah,2015).

\section{Pendapatan Desa}

Pendapatan Desa meliputi semua penerimaan uang melalui rekening desa yang merupakan hak desa dalam 1 (satu) tahun anggaran yang tidak perlu dibayar kembali oleh desa. Sedangkan Penerimaan Desa adalah uang yang berasal dari seluruh pendapatan desa yang masuk ke APBDes melalui rekening kas desa.

\section{Belanja Desa}

Belanja desa sebagaimana dimaksud dalam Pasal 8 ayat (1) huruf $b$, meliputi semua pengeluaran dari rekening desa yang merupakan kewajiban desa dalam 1 (satu) tahun anngaran yang tidak akan diperoleh pembayarannya kembali oleh desa. Belanja desa sebagaimana dimaksud pada ayat (1) dipergunakan rangka mendanai penyelenggaraan kewenangan desa.

\section{Pengelolaan Keuangan Desa}

Menurut Peraturan Menteri dalam Negeri Nomor 113 Tahun 2014 tentang Pengelolaan Keuangan Desa. Keuangan desa dikelola berdasarkan asas-asas transparan, akuntabel partisipatif, serta dilakukan dengan tata tertib dan disiplin anggaran. Pengelolaan keuangan desa dikelola dalam masa satu tahun anggaran yakni mulai tanggal 1 Januari sampai dengan tanggal 31 Desember. Pengelolaan keuangan desa tidak lepas dari kepala desa dan perangkat desa lainnya (Atmaja,2016).

\section{Kekayaan Desa}

Pada Peraturan Undang-Undang Nomor 6 Tahun 2014 pasal 76 menerangkan bahwa Aset Desa dapat berupa tanah kas desa, tanah ulayat, pasar desa, pasar hewan, tambahan perahu, bangunan desa, pelelangan ikan, pelelangan hasil pertanian, hutan milik desa, mata air milik desa, pemandian umum, dan aset lainnya milik Desa.

\section{Badan Usaha Milik Desa (BUMDes)}

Badan Usaha Milik Desa selanjutnya disingkat BUMDes adalah usaha desa yang dikelola oleh pemerintah desa. Badan Usaha Milik Desa (BUMDes) sebagai suatu lembaga ekonomi modal usahanya dibangun atas inisiatif masyarakat dan menganut asas mandiri. Ini berarti pemenuhan modal usaha Badan Usaha Milik Desa (BUMDes) harus bersumber dari masyarakat (Widodo, 2016). 


\section{Penelitian Terdahulu}

Atmaja (2016) dalam penelitian berjudul Analisis Pengelolaan Keuangan Dan Kekayaan Desa. Hasi Penelitian menunjukan tata kelola keuangan dan kekayaan pemerintah Desa ada yang sudah sesuai dan juga ada yang belum sesuai dengan perundang-undangan.

Iqsan (2016) dalam penelitian berjudul Transparansi Pemerintah Desa Dalam Penyusunan Anggaran Pendapatan Dan Belanja Desa (APBDes). Di Desa Long Nah Kecamatan Muara Ancalong Kabupaten Kutai Timur. Hasil penelitian menunjukan bahwa penerapan prinsip trnaspaansi oleh pemerintah desa dalam penyusunan anggaran pendapatan dan belanja desa (APBDes) di Desa Long Nah Kecamatan Muara Ancalong Kabupaten Kutai Timur sudah terlaksana dengan baik.

\section{METODE PENELITIAN Jenis Penelitian}

Jenis penelitian yang dilakukan adalah jenis penelitian deskriptif. Penelitian deskriptif meliputi pengumpulan data untuk diuji hipotesis atau menjawab pertanyaan mengenai status terakhir dari subjek penelitian. Dalam penelitian ini menggunakan jenis penelitian deskriptif dengan mengumpulkan data-data penelitian yang diperoleh dari Desa Motandoi dan Desa Motandoi Selatan Kecamatan Pinolosian Timur Kabupaten Bolaang Mongondow Selatan kemudian diuraikan secara rinci untuk mengetahui permasalahan penelitian dan mencari penyelesaiannya.

\section{Tempat dan Waktu Penelitian}

Lokasi penelitian yang diteliti penulis bertempat di Desa Motandoi dan Desa Motandoi Selatan Kecamatan Pinolosian Timur Kabupaten Bolaang Mongondow Selatan. Waktu penelitian dimulai pada Bulan Maret tahun 2017 sampai dengan bulan Mei 2017.

\section{Prosedur Penelitian}

Prosedur yang dilakukan dalam penelitian ini adalah sebagai berikut:

1. Persiapan dimulai dari pencarian judul penelitian yang dilakukan penulis.

2. Disposisi Pimpinan Dalam tahap ini dilakukan kunjungan ke objek penelitian dengan membawa pengantar yaitu surat penelitian dari pihak fakultas. Pihak pimpinan objek penelitian selanjutnya memberikan surat perintah yang menjelaskan izin persetujuan penelitian di Desa tersebut.

3. pengumpulan Data

Selanjutnya peneliti mengelola dan menganalisa data yang telah diperoleh dari objek penelitian. Peneliti mengumpulkan data pendukung penelitian dengan cara observasi dan melakukan wawancara.

4. Analisa Data Penelitian

Proses analisa data dilakukan dengan membandingkan pengelolaan keuangan Desa Motandoi dan Desa Motandoi Selatan dengan permendagri No.113 Tahun 2014 tentang pengelolaan keuangan desa. Peneliti menggunakan tabel perbandingan yang didalamnya memuat pos-pos pengelolaan keuangan desa dengan permendagri No.113Tahun 2014. Masalah yang dihadapi dalam tabel perbandingan kemudian diuraikan berdasarkan tahap pengelolaan keuangan desa, yaitu perencanaan, pelaksanaan, dan pertanggungjawaban APBDes.

5. Kesimpulan dan Saran 


\section{Jenis Data}

Jenis data yang digunakan dalam penelitian ini adalah jenis data kualitatif tentang objek penelitian yaitu berupa laporan keuangan pemerintah desa yang diterima dari objek penelitian.

\section{Sumber Data}

Dalam penelitian ini, peneliti menggunakan data primer berupa data diperoleh langsung dari objek penelitian seperti mendapatkan laporan keuangan desa. Sedangkan, data sekunder yang digunakan adalah dari literatur-literatur, dan buku-buku yang bersangkutan dengan APBDes.

\section{Teknik Pengumpulan Data}

Metode pengumpulan data dalam penelitian ini adalah sebagai berikut :

1. Teknik Observasi, adalah melakukan kunjungan atau pengamatan secara langsung pada objek penelitian untuk mendapatkan keterangan yang diperlukan.

2. Teknik Wawancara, adalah bentuk komunikasi antara dua orang, melibatkan seseorang yang ingin memperoleh informasi dari seseorang lainnya dengan mengajukan pertanyaan-pertanyaan. Penulis juga mengadakan tanya jawab langsung dengan pemerintah desa dan masyarakat desa mengenai data perencanaan, pelaksanaan dan pertanggungjawaban APBDes yang ada sesuai dengan masalah yang dibahas.

3. Teknik dokumentasi, adalah metode pengumpulan data dengan cara mempelajari dokumen, bukti-bukti atau catatan, arsip yang bersifat tulisan. Pengumpulan data dokumentasi menggunakan alat tulis manual maupun elektronik.

\section{Metode Analisis Data/ Teknik Analisis}

Metode analisis data yang digunakan dalam penelitian ini adalah metode deskriptif yaitu yang dimaksud untuk menggambarkan objek yang diteliti dan mengetahui tentang proses perencanaan, pelaksanaan, dan pertanggungjawaban APBDes. data-data tersebut dibandingkan dengan permendagri nomor 113 tahun 2014 tentang pengelolaan keuangan desa, sehingga bisa ditarik kesimpulan mengenai perencanaan, pelaksanaan, dan pertanggungjawaban APBDes di Desa Motandoi dan Desa Motandoi Selatan Kecamatan Pinolosian Timur Kabupaten Bolaang Mongondow selatan.

\section{1.}

\section{HASIL PENELITIAN DAN PEMBAHASAN}

\subsection{Hasil Penelitian}

\section{Proses Perencanaan APBDes Desa Motandoi}

Proses perencanaan keuangan Desa Motandoi meliputi Rencana Pembangunan Jangka Menengah Desa (RPJMDes) yang disusun secara berjangka dan ditetapkan dengan peraturan desa. Rencana Pembangunan Jangka Menengah Desa (RPJMDes) dalam jangka waktu 6 (enam) tahun melalui forum Musyawarah Perencanaan Pembangunan Desa (Musrenbangdes). Musrenbangdes adalah forum musyawarah yang membahas usulan-usulan rencana kegiatan pembangunan desa yang berpedoman pada prinsip perencanaan pembangunan partisipasi masyarakat desa, serta transparansi pemerintah kepada masyarakat. Musrenbangdes diadakan untuk membahas dan menyepakati rencana kerja pemerintah desa (RKPDes) dalam jangka pendek untuk 1 (satu) tahun berdasarkan RPJMDes.

\section{Proses Perencanaan APBDes Desa Motandoi Selatan}

Proses perencanaan keuangan Desa Motandoi Selatan meliputi Rencana Pembangunan Jangka Menengah Desa (RPJMDes) yang disusun secara berjangka dan 
ditetapkan dengan peraturan desa. Rencana Pembangunan Jangka Menengah Desa (RPJMDes) dalam jangka waktu 6 (enam) tahun melalui forum Musyawarah Perencanaan Pembangunan Desa (Musrenbangdes). Musrenbangdes adalah forum musyawarah yang membahas usulan-usulan rencana kegiatan pembangunan desa yang berpedoman pada prinsip perencanaan pembangunan partisipasi masyarakat desa, serta transparansi pemerintah kepada masyarakat. Musrenbangdes diadakan untuk membahas dan menyepakati rencana kerja pemerintah desa (RKPDes) dalam jangka pendek untuk 1 (satu) tahun berdasarkan RPJMDes.

\section{Proses Pelaksanaan APBDes Desa Motandoi}

Proses pelaksanaan APBDes adalah rangkaian kegiatan untuk melaksanakan APBDes dalam satu tahun anggaran yang dimulai dari 1 Januari sampai dengan 31 Desember, namun di Desa Motandoi dalam melaksanakan APBDes dalam satu tahun anggaran dimulai dari 1 Januari sampai dengan 30 Desember. Dalam anggaran pendapatan dan belanja desa (APBDes) disusunlah rencana anggaran biaya (RAB) untuk setiap kegiatan yang menjadi dasar pengajuan surat permintaan pembayaran (SPP).

\section{Proses Pelaksanaan APBDes Desa Motandoi Selatan}

Proses pelaksanaan APBDes adalah rangkaian kegiatan untuk melaksanakan APBDes dalam satu tahun anggaran yang dimulai dari 1 Januari sampai dengan 31 Desember, namun di Desa Motandoi Selatan dalam melaksanakan APBDes dalam satu tahun anggaran dimulai dari 1 Januari sampai dengan 30 Desember. Dalam anggaran pendapatan dan belanja desa (APBDes) disusunlah rencana anggaran biaya (RAB) untuk setiap kegiatan yang menjadi dasar pengajuan surat permintaan pembayaran (SPP).

\section{Proses Pertanggungjawaban APBDes Desa Motandoi}

Proses pertanggungjawaban Desa Motandoi, bendahara desa wajib melaporkan penggunaan dana anggaran pendapatan dan belanja desa (APBDes) kepada kepala desa. Tanggungjawab tersebut harus dibuat secara rinci dan sesuai dengan ketentuan yang berlaku. Kewajiban untuk melaporkan pertanggungjawaban pengelolaan keuangan desa menuntut bagi Bendahara untuk mampu menginterpretasikan peraturan-peraturan tentang pertanggungjawaban. Pertanggungjawaban pelaksanaan APBDes terdiri dari penetapan pelaksanaan APBDes dan penyampaian laporan pertanggungjawaban pelaksanaan APBDes.

\section{Proses Pertanggungjawaban APBDes Desa Motandoi Selatan}

Proses pertanggungjawaban Desa Motandoi Selatan, bendahara desa wajib melaporkan penggunaan dana anggaran pendapatan dan belanja desa (APBDes) kepada kepala desa. Tanggungjawab tersebut harus dibuat secara rinci dan sesuai dengan ketentuan yang berlaku. Pertanggungjawaban pelaksanaan APBDes terdiri dari penetapan pelaksanaan APBDes dan penyampaian laporan pertanggungjawaban pelaksanaan APBDes. Sekretaris desa mencatat rancangan peraturan desa tentang pertanggungjawaban pelaksanaan APBDes dan rancangan keputusan kepala desa tentang pertanggungjawaban kepala desa.

\subsection{Pembahasan}

\section{Analisis Perencanaan Anggaran Pendapatan dan Belanja Desa Motandoi Dihubungkan Dengan Permendagri No.113 Tahun 2014}

Hasil penelitian yang diperoleh dari Desa Motandoi bahwa perencanaan keuangan Desa sudah sesuai dengan Permendagri No. 113 Tahun 2014 yaitu Sekretaris Desa menyusun rancangan Peraturan Desa tentang APBDes berdasarkan RKPDes tahun berkenaan. Sekretaris Desa menyampaikan rancangan Peraturan Desa tentang APBDes kepada Kepala Desa, 
sebaiknya untuk Desa Motandoi dan Motandoi Selatan saat sekretaris mencatat rancangan peraturan desa tentang APBDes berdasarkan RKPDes kepala desa harus melakukan pemeriksaan kembali dan mengoreksi jika terjadi kesalahan dalam rancangan Peraturan Desa. Rancangan Peraturan Desa tentang APBDes dibahas dan disepakati Kepala Desa dan badan permusyawaratan desa (BPD. Rancangan Peraturan Desa tentang APBDes disepakati bersama paling lambat bulan oktober tahun berjalan. Rancangan PERDES tentang APBDes yang telah disepakati bersama disampaikan oleh Kepala Desa kepada Bupati/Walikota melalui camat atau sebutan lain paling lambat 3 (tiga) hari sejak disepakati untuk dievaluasi. Bupati/ walikota menetapkan hasil rancangan APBDes paling lama 20 (dua Puluh) hari kerja kepada kepala desa sejak diterima ancangan peraturan desa tentang APBDes.

\section{Analisis Perencanaan Anggaran Pendapatan dan Belanja Desa Motandoi Selatan Dihubungkan Dengan Permendagri No.113 Tahun 2014}

Hasil penelitian yang diperoleh dari Desa Motandoi Selatan bahwa perencanaan keuangan Desa sudah sesuai dengan Permendagri No. 113 Tahun 2014 yaitu Sekretaris Desa menyusun rancangan Peraturan Desa tentang APBDes berdasarkan RKPDes tahun berkenaan. Sekretaris Desa menyampaikan rancangan Peraturan Desa tentang APBDes kepada Kepala Desa, sebaiknya untuk Desa Motandoi dan Motandoi Selatan saat sekretaris mencatat rancangan peraturan desa tentang APBDes berdasarkan RKPDes kepala desa harus melakukan pem eriksaan kembali dan mengoreksi jika terjadi kesalahan dalam rancangan Peraturan Desa. Rancangan Peraturan Desa tentang APBDes dibahas dan disepakati Kepala Desa dan badan permusyawaratan desa (BPD. Rancangan Peraturan Desa tentang APBDes disepakati bersama paling lambat bulan oktober tahun berjalan. Rancangan PERDES tentang APBDes yang telah disepakati bersama disampaikan oleh Kepala Desa kepada Bupati/Walikota melalui camat atau sebutan lain paling lambat 3 (tiga) hari sejak disepakati untuk dievaluasi. Bupati/ walikota menetapkan hasil rancangan APBDes paling lama 20 (dua Puluh) hari kerja

kepada kepala desa sejak diterima ancangan peraturan desa tentang APBDes.

\section{Analisis Pelaksanaan Anggaran Pendapatan dan Belanja Desa Motandoi Dihubungkan Dengan Permendagri No.113 Tahun 2014}

Desa Motandoi dalam pelaksanaan sudah sesuai dengan Permendagri No.113 Tahun 2014 yaitu Sekretaris Desa menyusun rancangan Peraturan Desa tentang APBDes berdasarkan RKPDes tahun berkenaan. Sekretaris Desa menyampaikan rancangan Peraturan Desa tentang APBDes kepada Kepala Desa, sebaiknya untuk Desa Motandoi dan Motandoi Selatan saat sekretaris mencatat rancangan peraturan desa tentang APBDes berdasarkan RKPDes kepala desa harus melakukan pemeriksaan kembali dan mengoreksi jika terjadi kesalahan dalam rancangan Peraturan Desa. Rancangan Peraturan Desa tentang APBDes dibahas dan disepakati Kepala Desa dan badan permusyawaratan desa (BPD). Rancangan Peraturan Desa tentang APBDes disepakati bersama paling lambat bulan oktober tahun berjalan. Rancangan PERDES tentang APBDes yang telah disepakati bersama disampaikan oleh Kepala Desa kepada Bupati/Walikota melalui camat atau sebutan lain paling lambat 3 (tiga) hari sejak disepakati untuk dievaluasi. Bupati/ walikota menetapkan hasil rancangan APBDes paling lama 20 (dua Puluh) hari kerja kepada kepala desa sejak diterimanya rancangan peraturan desa tentang APBDes.

\section{Analisis Pelaksanaan Anggaran Pendapatan dan Belanja Desa Motandoi Selatan Dihubungkan Dengan Permendagri No.113 Tahun 2014}

Desa Motandoi Selatan dalam Pelaksanaan sudah sesuai dengan Permendagri No.113 Tahun 2014 yaitu Sekretaris Desa menyusun rancangan Peraturan Desa tentang APBDes 
berdasarkan RKPDes tahun berkenaan. Sekretaris Desa menyampaikan rancangan Peraturan Desa tentang APBDes kepada Kepala Desa, sebaiknya untuk Desa Motandoi dan Motandoi Selatan saat sekretaris mencatat rancangan peraturan desa tentang APBDes berdasarkan RKPDes kepala desa harus melakukan pemeriksaan kembali dan mengoreksi jika terjadi kesalahan dalam rancangan Peraturan Desa. Rancangan Peraturan Desa tentang APBDes dibahas dan disepakati Kepala Desa dan badan permusyawaratan desa (BPD). Rancangan Peraturan Desa tentang APBDes disepakati bersama paling lambat bulan oktober tahun berjalan. Rancangan PERDES tentang APBDes yang telah disepakati bersama disampaikan oleh Kepala Desa kepada Bupati/Walikota melalui camat atau sebutan lain paling lambat 3 (tiga) hari sejak disepakati untuk dievaluasi. Bupati/ walikota menetapkan hasil rancangan APBDes paling lama 20 (dua Puluh) hari kerja kepada kepala desa sejak diterimanya rancangan peraturan desa tentang APBDes.

\section{Analisis Pertanggungjawaban Anggaran Pendapatan dan Belanja Desa Motandoi Dihubungkan Dengan Permendagri No.113 Tahun 2014}

Hasil Penelitian yang diperoleh dari lapangan dalam pertanggungjawaban keuangan Desa Motandoi, dimana hal ini terjadi ketidaksesuaian yaitu pertanggungjawaban belum diinformasikan kepada seluruh masyarakat Desa Motandoi, berdasarkan Permendagri No.113 Tahun 2014 Pasal 40 yang mengatur bahwa laporan pertanggungjawaban realisasi pelaksanaan APBDes diinformasikan kepada masyarakat secara tertulis dan dengan media yang mudah diakses oleh masyarakat. Hal ini, Inspektorat mendapatkan temuan di Desa Motandoi mengenai Register Surat Permintaan Pembayaran (SPP) Tahun Anggaran 2016 karena jumlahnya tidak sesuai dengan Register Kwitansi Pembayaran Tahun Anggaran 2016 dan telah diberikan kesempatan untuk Desa Motandoi dalam melengkapi dokumen pendukungnya. Hasil dari pemeriksaan Inspektorat ke Desa diberikan kepada Bupati Bolaang Mongondow Selatan sebagai tanda bukti bahwa telah diperiksa.

\section{Analisis Pertanggungjawaban Anggaran Pendapatan dan Belanja Desa Motandoi Selatan Dihubungkan Dengan Permendagri No.113 Tahun 2014}

Desa Motandoi Selatan Pertanggungjawaban keuangan desa sudah sesuai dengan permendagri yaitu Kepala Desa Menyampaikan Laporan Realisasi Pelaksanaan APBDes kepada Bupati setiap akhir tahun anggaran, Laporan Realisasi Pelaksanaan APBDes terdiri dari Pendapatan, belanja, dan pembiayaan, Peraturan Desa tentang Laporan Pertangungjawaban Realisasi Pelaksanaan APBDes, dan format Laporan Kekayaan Milik Desa per 31 Desember Tahun Anggaran berkenaan, Laporan realisasi dan laporan pertanggungjawaban pelaksanaan APBDes diinformasikan kepada masyarakat secara tertulis dan dengan media informasi yang mudah diakses oleh masyarakat dan Media Informasi antara lain papan pengumuman, radio komunitas, dan media informasi lainnya.

\section{KESIMPULAN DAN SARAN}

\subsection{Kesimpulan}

Berdasarkan pembahasan yang telah disajikan pada bab sebelumnya maka dapat ditarik kesimpulan sebagai berikut :

1. Dalam proses perencanaan dan pelaksanaan anggaran pendapatan dan belanja desa (APBDes) tahun 2016 Desa Motandoi dan Motandoi Selatan sudah sesuai dengan Peraturan Menteri Dalam Negeri No.113 Tahun 2014.

2. Dalam proses pertanggungjawaban Desa Motandoi terjadi tetidaksesuaian yaitu dimana keuangan desa Motandoi tidak diinformasikan kepada masyarakat desa Motandoi, hal ini tidak sesuai dengan Permendagri Nomor 113 Tahun 2014 yaitu yang mengatur bahwa laporan pertanggungjawaban realisasi pelaksanaan APBDes 
diinformasikan kepada. masyarakat secara tertulis dan dengan media yang mudah diakses oleh masyarakat, sedangkan Desa Motandoi Selatan dalam proses pertanggungjawaban sudah sesuai dengan Permendagri No.113 Tahun 2014.

3. Penerapan permendagri nomor 113 tahun 2014 di Desa Motandoi dan Desa Motandoi selatan ternyata dapat membantu kepala desa, sekretaris desa, bendahara desa, dan badan permusyawaratan desa untuk lebih siap dalam pengelolaan keuangan desa agar dapat menyajikan laporan keuangan desa yang berguna dan dapat mensejahterakan masyarakat desa.

\subsection{Saran}

Berdasarkan kesimpulan diatas peneliti memberikan saran sebagai berikut:

1. Kiranya untuk tahun 2017 dalam pembuatan laporan kuangan APBDes, hendaknya Desa Motandoi dan Motandoi Selatan terus menggunakan Peraturan Menteri Dalam Negeri No.113 Tahun 2014 dalam menyajikan laporan keuangan desa. Agar Pengelolaan Keuangan Desa dapat berwujud dengan efektif dan efisien serta dapat bermanfaat bagi pengguna laporan keuangan desa.

2. Pentingnya sumber daya manusia juga menjadi hal yang perlu diperhatikan, karena SDM yang berkualitas dan kompeten sangat dibutuhkan agar mampu bekerja dengan baik dan menghasilkan laporan keuangan yang berkualitas.

3. Selain itu untuk peneliti selanjutnya agar dapat melakukan penelitian pada beberapa Desa yang lain di Kecamatan Pinolosian Timur Kabupaten Bolaang Mongondow Selatan agar dapat menggambarkan secara umum dan luas penyajian laporan keuangan pemerintah desa.

\section{DAFTAR PUSTAKA}

Akbar, Lukmanul, Dipo. 2015. "Peran Pemerintahan Desa Dalam Penyusunan APBDes Perspektif Undang-Undang Nomor 6 Tahun 2014 Tentang Desa".

Atmaja, A, Dinar. 2016. “Analisis Pengelolaan Keuangan Dan Kekayaan Desa”.

Badriyah, hurriyah. 2015. Buku Pintar Akuntansi Dagang Untuk Orang Awam. Penerbit HB.

Bahri, Syaiful. 2016. Pengatar Akuntansi Berdasarkan SAK ETAP dan IFRS. Penerbit Andi. Yogyakarta.

Benedicto, Dkk. 2013. "The Role Of Accounting In Public Governance Process".

Diansari, E, Rani. "Analisa Implementasi Alokasi Dana Desa (ADD) Kasus Seluruh Desa Di Kecamatan Kledung Kabupaten Temanggung Tahun 2013”.

Dewanti, D, W, Elsa,2015. "Analisis Perencanaan Pengelolaan Keuangan Desa di Desa Boreng (Studi Kasus Pada Desa Boreng Kecamatan Lumajang Kabupaten Lumajang)".

Dissanayaka, Dkk. 2015. “ The Development Of Public Sector Accounting And Financial Reporting In Sri Lanka”. 